\title{
qPCR Quantification of Pathogenic Guignardia citricarpa and Nonpathogenic G. mangiferae in Citrus
}

Jiahuai Hu, Evan G. Johnson, Nan-Yi Wang, Tiago Davoglio, and Megan M. Dewdney, Citrus Research and Education Center, University of Florida, Lake Alfred 33850 \begin{abstract}
pathogenic G. mangiferae in citrus. Plant Dis. 98:112-120.
Citrus black spot, a major citrus disease caused by Guignardia citricarpa, was recently introduced in Florida. The nonpathogenic fungal endophyte G. mangiferae is commonly found in the same citrus tissues as G. citricarpa. Quantitative polymerase chain reaction (qPCR) assays based on internal transcribed spacer (ITS)-1 genes were developed to detect, quantify, and distinguish between these morphologically similar organisms in environmental samples. The primer/probe sets GCITS and GMITS were more than $95 \%$ efficient in single-set reactions in complex environmental DNA samples. Detection of $10 \mathrm{fg}$ of G. citricarpa and G. mangiferae DNA was possible. Pycnidiospore disruption resulted in detection of single pycnidiospores with 78 (59 to $102 ; 95 \%$
\end{abstract}

Abstract

Hu, J., Johnson, E. G., Wang, N.-Y., Davoglio, T., and Dewdney, M. M. 2014. qPCR quantification of pathogenic Guignardia citricarpa and non-

confidence interval $[\mathrm{CI}])$ and 112 (92 to $136 ; 95 \% \mathrm{CI})$ ITS copies for G. citricarpa and G. mangiferae, respectively. Detection was from partially decomposed leaves where fruiting bodies cannot be morphologically distinguished. Temperature and wetting period have significant effects on Guignardia spp. pseudothecia production in leaf litter. Based on relative biomass or the proportion of nuclei detected, $G$. citricarpa and $G$. mangiferae respond more strongly to wetting period than temperature. This qPCR assay will provide additional epidemiological data on black spot in tissues where G. citricarpa and G. mangiferae are not easily distinguished.
Guignardia citricarpa Kiely (anamorph Phyllosticta citricarpa (McAlpine) Aa), the causal agent of citrus black spot, is an economically important and destructive pathogen that attacks Citrus, Poncirus, and Fortunella spp. and their hybrids $(6,22)$. This pathogen often causes diverse fruit blemishes and fruit drop, leading to significant yield loss, especially on late-maturing sweet orange $(33,38)$, but rarely causes leaf lesions on most cultivars except lemon (33). Citrus black spot has been present for decades in many humid subtropical citrus production regions in Africa, Australia, Southeast Asia, and South America (22,32). Recently discovered in a South Florida commercial grove in early 2010 (36), the disease is newly emerging on Florida citrus, and major trade restrictions could be imposed on the export of fresh fruit from Florida $(5,36,44)$. Despite the immediate quarantine measures implemented to prevent further spread, the infected area has expanded in commercial groves. A detailed understanding of the life cycle of this pathogen, such as inoculum production and the epidemiology under Florida environmental conditions, is essential to formulate effective management strategies to stem the expansion of this emerging citrus disease.

Black spot is difficult to manage because of the long period of fruit susceptibility and simultaneous presence of young and mature fruit on some cultivars. Secondary infection can occur from mature to young fruit via the pycnidiospores. The life cycle of $G$. citricarpa has two phases: pathogenic and saprophytic $(4,6,22)$. The pathogen reproduces in the leaf litter beneath the trees, where pseudothecia are formed and release airborne ascospores for much

Corresponding author: M. Dewdney, E-mail: mmdewdney@ufl.edu

J. Hu and E. G. Johnson contributed equally to the manuscript.

* The $\boldsymbol{e}$-Xtra logo stands for "electronic extra" and indicates that two supplementary figures are available online and that Figure 6 appears in color online.

Accepted for publication 5 August 2013.

http://dx.doi.org/10.1094/PDIS-04-13-0465-RE

(C) 2014 The American Phytopathological Society of the year $(15,19,25,26,34)$. Spores are deposited on leaf or fruit surfaces, where they germinate under moist conditions and produce latent infections. Asymptomatic leaves with latent infections are an efficient vehicle to spread the pathogen from one citrus grove to other groves $(28,29)$ and, potentially, from one continent to another. Symptoms usually develop on maturing fruit from the fall to early spring. Sometimes symptom development can occur after fruit is harvested and shipped. Pycnidia formed on fruit, twigs, and leaf litter produce pycnidiospores that can be efficiently disseminated by water splash (38-40). The pycnidiospores also can infect young fruit and leaves present on the tree. For pycnidiospores to be a major source of inoculum, significant summer rainfall and overlapping mature and young fruit are required (38). The disease is mainly managed by summer fungicide applications (up to 6 applications) of strobilurin fungicides and copper products $(1,11,37)$. Fungicide efficacy can be improved by leaf litter removal or enhanced leaf litter decomposition (7,39). Effective implementation of these management practices requires an accurate quantification assay to monitor the inoculum dynamics in a citrus grove.

Two species of Guignardia are known to be associated with citrus in Florida. A morphologically identical but nonpathogenic species, G. mangiferae (anamorph $P$. capitalensis), is an endophytic fungus on plants in 21 families, including citrus $(4,13,17,29)$. In Brazil and China, additional endophytic species $(P$. citribraziliensis and $P$. citrichinaensis) were found associated with citrus $(17,45)$ but it is unknown whether these endophytes are present in Florida. G. mangiferae is frequently isolated from both symptomatic and asymptomatic citrus material. It has been confused with $G$. citricarpa for many years and appears to inhabit the same ecological niches $(4,6,24,29)$. G. mangiferae grows more quickly on artificial media, has a complete margin, and readily produces pseudothecia. In contrast, G. citricarpa does not produce viable pseudothecia in culture, grows slowly, and has a lobed margin (4). Direct isolation on selective media and culturing on oatmeal media allows accurate detection and differentiation of these two Guignardia spp. but this method requires 10 to 14 days to complete, expertise to do the isolations, culturing, and examination of morphology, and has a relatively low success rate $(4,29,44)$.

Molecular detection methods have become an increasingly important diagnostic tool because of speed, accuracy, and sensitivity, 
and several have been developed for specific detection of $G$. citricarpa $(9,14,18,28,33,44)$. These polymerase chain reaction (PCR) protocols include primers derived from internal transcribed spacers (ITSs) $(9,14,28,33,44)$, random amplified polymorphic DNA markers (18), the chitin synthase gene sequence, and the external transcribed spacers (33). Combined with direct isolation from symptomatic fruit $(9,28,33)$, species-specific PCR assays have become the current standard detection method for G. citricarpa (5). Most of the published PCR assays are not quantitative and are used for $G$. citricarpa detection in regulatory situations. They are not as suitable for ecological and biological studies of G. citricarpa.

Quantitative PCR (qPCR) has been broadly used to detect and quantify fungal pathogens $(3,10,20,35)$. A qPCR method developed by van Gent-Pelzer et al. to detect $G$. citricarpa for phytosanitary purposes (44) has proven robust. The original goal of this current study was to develop a duplex qPCR assay for G. citricarpa and $G$. mangiferae based on this method to investigate the interactions between these two species in Florida. Significant interactions among the G. citricarpa primers and probes from the van GentPelzer (44) study with those developed for G. mangiferae were encountered, warranting the development of new G. citricarpa primers and probes for duplex qPCR.

To better understand the epidemiology and ecology of G. citricarpa requires more information about the interaction between the two citrus-associated Guignardia spp. in Florida. The ability to measure the relative proportions of the DNA of the two fungi in environmental samples, including leaves, fruit, leaf litter, and airborne spore samples, is critical for answering many epidemiological and ecological questions about G. citricarpa and how G. mangiferae may interact with it. One of the least studied aspects of $G$. citricarpa ecology is pseudothecia formation in leaf litter. The pseudothecia of the two fungi are not easily distinguished visually in the leaf litter, and isolations in the presence of many fast-growing saprophytic fungi can be difficult and time consuming. Temperature and wetting periods influence the number of pseudothecia formed in leaf litter of other fungi $(16,31,43)$ and it is expected that a similar effect would be seen with $G$. citricarpa.

The objectives of this study were to develop, optimize, and validate sensitive and reliable qPCR protocols for detecting and quantifying $G$. citricarpa and $G$. mangiferae in environmental samples. The primers and probes were then used to determine the relative biomass of the two fungi in leaf litter samples.

\section{Materials and Methods}

Isolates. Organisms used in this study are listed in Table 1 and all fungal isolates were single spored. The G. citricarpa isolate was recovered from typical freckle spot symptoms on 'Valencia' sweet

Table 1. List of fungi, oomycete, and bacteria species tested for specificity with the Guignardia citricarpa (GCITS) and G. mangiferae (GMITS) primer/probe sets and quantitative polymerase chain reaction (qPCR) cycle threshold $\left(\mathrm{C}_{\mathrm{t}}\right)$ values for each specificity test $\mathrm{t}^{\mathrm{a}}$

\begin{tabular}{llcc}
\hline Species & Host & GCITS & GMITS \\
\hline Guignardia citricarpa & Citrus & 27.1 & NA \\
G. mangiferae & Citrus & NA & 27.5 \\
G. bidwellii & Grape & NA & NA \\
Phytophthora nicotianae & Citrus & NA & NA \\
P. palmivora & Citrus & NA & NA \\
Alternaria alternata & Citrus & NA & NA \\
Diaporthe citri & Citrus & NA & NA \\
Elsinoë fawcettii & Citrus & NA & NA \\
Mycosphaerella citri & Citrus & NA & NA \\
M. fijiensis & Banana & NA & NA \\
Xanthomonas citri subsp. citri & Citrus & NA & NA \\
$X$. alfalfae subsp. citrumelonis & Citrus & NA & NA \\
Colletotrichum acutatum & Citrus & NA & NA \\
C. gloeosporioides & Citrus & NA & NA \\
\hline
\end{tabular}

${ }^{\mathrm{a}} \mathrm{GCITS}=\mathrm{C}_{\mathrm{t}}$ values of $\mathrm{qPCR}$ primer and probe set for G. citricarpa, GMITS $=\mathrm{C}_{\mathrm{t}}$ values of qPCR primer and probe set for G. mangiferae, and $\mathrm{NA}=$ no amplification after 50 cycles. orange fruit and G. mangiferae was isolated from fresh citrus leaves before black spot was found in Florida. All other species used in this study (Table 1) were from the laboratory collection and grown out for total genomic DNA (gDNA) isolation.

Total gDNA isolation from fungal and bacterial cultures. Cellophane disks overlaid onto potato dextrose agar (PDA) were inoculated with mycelial suspensions of the fungal isolates listed in Table 1. Cultures were grown for at least 1 week at $25^{\circ} \mathrm{C}$ and 200 $\mathrm{mg}$ of mycelium was harvested from the cellophane. The mycelia were placed into $2.0-\mathrm{ml}$ screw cap tubes with sterile stainless-steel beads ( $5 \mathrm{~mm}$ in diameter) and homogenized twice with the TissueLyzer II (Qiagen Inc.) under liquid nitrogen for $30 \mathrm{~s}$ at $30 \mathrm{~Hz}$. Total gDNA was then extracted from the homogenized fungal samples using the DNeasy Plant Mini Kit (Qiagen Inc.) according to the manufacturer's instructions. Bacterial total gDNA was isolated from pure bacteria cultures using the DNeasy Blood and Tissue Kit (Qiagen Inc.) per the manufacturer's instructions. A final volume of $100 \mu$ of DNA eluate was obtained from both extraction types. The concentration and quality of each gDNA sample was determined spectrophotometrically by absorbance at $260 / 280 \mathrm{~nm}$ using a Nanodrop 1000 and software ND-1000 (v3.3.0; Thermo Fisher Scientific). All gDNA samples were stored at $-20^{\circ} \mathrm{C}$ until use.

Primers and probe design. To design species-specific primers and probes, the ITS-1 region of ribosomal DNA, actin (act), and translation elongation factor $1 \alpha($ tef $1-\alpha)$ genes from $G$. citricarpa and $G$. mangiferae were retrieved from the National Center for Biotechnology Information (NCBI) nucleotide database (http:// www.ncbi.nlm.nih.gov/nuccore) and examined for regions with high polymorphism between the two Guignardia spp., P. citriasiana, $P$. citribraziliensis, and $P$. citrichinaensis (Supplementary Figure S1) but conserved within species. Candidate sequences were tested for homology to other citrus pathogens using NCBI Nucleotide BLAST (http://www.ncbi.nlm.nih.gov/BLAST/). The GenBank accession numbers of the sequences used for primer design are listed in Table 2. The primers and probes were designed using the "TaqMan search" function of primer design software AlleleID 7 (PREMIER Biosoft International). The potential formation of secondary structures and interactions among the oligonucleotide sequences were also investigated in silico using this software. Any proposed primer and probe designs with low $-\Delta \mathrm{G}$ were discarded. Primer and probe selectivity and specificity was verified with BLASTN on the NCBI server. The selected G. citricarpa probe was labeled with a $5^{\prime} \mathrm{Cy} 5$ fluorescent reporter dye and a $3^{\prime}$ Iowa Black Quencher RQ. The G. mangiferae probe was labeled with a $5^{\prime}$ FAM fluorescent reporter dye and a $3^{\prime}$ Black Hole Quencher 1. All primers and probes were synthesized by Integrated DNA Technologies Inc.

Construction and DNA extraction of plasmids for standards. The ITS-1 regions from G. citricarpa and G. mangiferae isolates were amplified separately using primer pairs GCITS and GMITS (Table 3 ) in a conventional $25-\mu \mathrm{l}$ PCR reaction (400 $\mathrm{nM}$ each pri-

Table 2. GenBank accession numbers of the sequences used in the development of quantitative polymerase chain reaction assay

\begin{tabular}{lcl}
\hline Accession number & ${\text { Target genes, } \text { region }^{\mathbf{a}}}$ & \multicolumn{1}{c}{ Species } \\
\hline JF261432 & ITS & Guignardia citricarpa \\
FJ538430 & ITS & G. citricarpa \\
FJ538373 & ITS & G. citricarpa \\
JF261437 & ITS & G. mangiferae \\
FJ538457 & ITS & G. mangiferae \\
FJ538392 & ITS & G. mangiferae \\
FJ538360 & ITS & Phyllosticta citriasiana \\
JF261436 & ITS & P. citribraziliensis \\
JN791595 & ITS & P. citrichinaensis \\
FJ538430 & Actin & G. citricarpa \\
FJ538457 & Actin & G. mangiferae \\
FJ538375 & tef-1 $\alpha$ & G. citricarpa \\
JF261506 & tef-1 $\alpha$ & G. mangiferae \\
\hline
\end{tabular}

${ }^{\mathrm{a}}$ ITS $=$ Internal transcribed spacer and tef- $1 \alpha=$ translation elongation factor $1-\alpha$ gene. 
mer, $200 \mu \mathrm{M}$ each dNTP, and 2.5 units of Hotstar Taq DNA polymerase [Qiagen Inc.]) with cycle parameters of an initial activation step of $95^{\circ} \mathrm{C}$ for $15 \mathrm{~min} ; 40$ cycles at $94^{\circ} \mathrm{C}$ for $30 \mathrm{~s}, 60^{\circ} \mathrm{C}$ for $30 \mathrm{~s}$, and $72^{\circ} \mathrm{C}$ for $30 \mathrm{~s}$; and a final $10 \mathrm{~min}$ at $72^{\circ} \mathrm{C}$ (PTC-200 thermocycler; MJ Research). PCR products were purified with the QIAquick PCR purification kit (Qiagen Inc.), ligated into the pDrive cloning vector $(3.85 \mathrm{~kb})$ with the Qiagen PCR cloning kit, and used to transform Escherichia coli strain DH5 $\alpha$. The clones were confirmed by colony PCR using the primer pairs GCITS and GMITS. The cloned plasmids contained $84 \mathrm{bp}$ from GCITS and $111 \mathrm{bp}$ from GMITS and were named pGC1and pGM1, respectively. Plasmid DNA (pDNA) was extracted from E. coli cultures grown overnight at $37^{\circ} \mathrm{C}$ in Luria-Bertani broth supplemented with ampicillin (100 $\mu \mathrm{g} / \mathrm{ml})$ using the Qiagen miniprep kit.

Specificity. All reported qPCR was done with a CFX96 RealTime PCR detection system (Bio-Rad Laboratories). SYBR Green qPCR was conducted to evaluate primer specificity, potential primer-dimer formation, and nonspecific amplification products by melt-curve analysis. The $25-\mu \mathrm{l}$ reaction contained $5 \mu$ l of template DNA from G. citricarpa, G. mangiferae, or sterile deionized water as the non-template control (NTC) and $400 \mathrm{nM}$ final concentrations of forward and reverse primers in the EvaGreen Supermix (Bio-Rad Laboratories). Melt-curve analysis from 55 to $95^{\circ} \mathrm{C}$ was performed at the end of 50 cycles. In addition, the specificity of GCITS and GMITS assays was evaluated with 10-ng gDNA samples from fungal and bacterial species commonly associated with citrus in Florida (Table 1). DNA samples were also included from closely related $G$. bidwellii from grape and unrelated Mycosphaerella fijiensis from banana (Table 1). Sterile deionized water was included as an NTC with each qPCR assay and the amplifications were performed in triplicate. The primers were considered specific if the fluorescence signal did not pass the threshold within 50 cycles and no PCR products were visible via electrophoresis in $2 \%$ agarose with only nontarget DNA present.

Optimization of GCITS and GMITS qPCR assays. The GCITS or GMITS qPCR assays were examined separately at a range of primer (50 to $800 \mathrm{nM}$ ) and probe (50 to $400 \mathrm{nM}$ ) concentrations to determine optimal conditions for the assay. A range of $\mathrm{MgCl}_{2}$ concentrations between 1.5 and $5 \mathrm{nM}$ and annealing temperatures between 55 and $63^{\circ} \mathrm{C}$ were also tested. The qPCR assay, in a final volume of $25 \mu \mathrm{l}$, was run with Qiagen Hotstar Taq DNA polymerase $(0.625 \mathrm{U})$ according to the supplier's protocol, $400 \mathrm{nM}$ forward and reverse primers, $200 \mathrm{nM}$ probe, and $4 \mu \mathrm{l}$ of template DNA or sterile water. The thermal cycle conditions were as follows: initial activation step of $95^{\circ} \mathrm{C}$ for $10 \mathrm{~min}$, then 50 cycles of $94^{\circ} \mathrm{C}$ for $15 \mathrm{~s}$ and $59^{\circ} \mathrm{C}$ for $1 \mathrm{~min}$.

Standard curves for quantification. Standard curves for the GCITS and GMITS assays were prepared with a 10-fold dilution series of gDNA or pDNA. The 10-fold dilution series of gDNA for both Guignardia spp. ranged from $2.5 \mathrm{ng} / \mu \mathrm{l}$ to $2.5 \mathrm{fg} / \mu \mathrm{l}$ unless specified. Copy number of pGC1 and pGM1 was estimated using the number of base pairs (3,934 and 3,961 bp, respectively) and $650 \mathrm{Da}$, the average molecular mass of a base pair in doublestranded DNA (42). Consequently, one copy of the pGC1 and pGM1 plasmids was estimated to be $4.31 \times 10^{-6}$ and $4.34 \times 10^{-6}$ $\mathrm{pg}$, respectively. The initial concentration of pGC1was $2.50 \times 10^{6}$ copies/ $\mu$ and that of $\mathrm{pGM} 1$ was $1.11 \times 10^{6}$ copies/ $\mu \mathrm{l}$ in sterile water. Samples were run in triplicate.

Additionally, standard curves of the gDNA of G. citricarpa or G. mangiferae, ranging from $2.5 \mathrm{ng} / \mu \mathrm{l}$ to $2.5 \mathrm{fg} / \mu \mathrm{l}$, were made in either sterile water or gDNA at $2.5 \mathrm{ng} / \mu \mathrm{l}$ from the opposite organism to that used in the assay. Samples $(4 \mu \mathrm{l})$ at each concentration were run in triplicate.

Inhibitive effect of host DNA extracts on qPCR assay. Total DNA extracts from both healthy and partially decomposed citrus leaves were used to evaluate the potentially inhibitive effect of host DNA and co-purified compounds from decomposing leaves on the amplification and quantification of GCITS and GMITS assays. Fresh citrus leaves were collected from Valencia trees in Lake Alfred, FL, where black spot has never been observed. Partially decomposed leaf samples were collected under Valencia trees with citrus black spot symptoms in Immokalee, FL. Leaf disks $(7 \mathrm{~mm}$ in diameter) were cut from each sampled leaf using a cork borer and five leaf discs were arbitrarily pooled into one sample. The leaf discs were homogenized by bead beating as described above. The total DNA from healthy leaf samples was isolated using the DNeasy Plant Mini Kit per the manufacturer's instructions. Total DNA for partially decomposed leaves were extracted with three methods: (i) the PowerSoil DNA isolation kit (Mo Bio Laboratories), according to the manufacturer's instructions; (ii) the PowerSoil DNA isolation kit with tissue homogenization by bead beating, as described above; and (iii) DNeasy Plant Mini Kit according to the manufacturer's instructions. A final volume of $100 \mu \mathrm{l}$ of eluate was obtained from all extraction methods. The extractions were done three times for each method. The extracts were diluted $1 / 10$ and $1 / 100$. The first inhibition experiment spiked the three extract types with an additional $10^{5}$ copies of pDNA for both primer/probe sets. The samples were also tested without the pDNA. Observed DNA quantification was compared with the expected sum of $10^{5}$ copies and the unspiked quantification. The second experiment determined whether there was a target DNA concentration-dependent inhibition in different background extracts. Sterile water, healthy host tissue, partially decomposed leaf tissue extracted with the PowerSoil DNA isolation kit with bead beating tissue homogenization, and a 1/10 dilution of the partially decomposed leaf extract were used as backgrounds. A 10-fold pDNA dilution series was prepared in each of the background solutions and run in triplicate. The experiment was conducted twice.

Quantification of pycnidiospores. Pycnidiospore suspensions of G. citricarpa or G. mangiferae were harvested from 2-week-old pure cultures maintained on PDA by flooding the plate with $3 \mathrm{ml}$ of a sterile $0.01 \%$ ( $\mathrm{vol} / \mathrm{vol})$ Tween 20 solution. The spore suspensions were washed with sterile distilled water three times by centrifugation for $5 \mathrm{~min}$ at $5,000 \times \mathrm{g}$. The pellet was suspended in 100 $\mu \mathrm{l}$ of sterile distilled water and the concentration of pycnidiospores was determined using a Neubauer hemocytometer (Reichert). The spore suspensions were adjusted to $2.5 \times 10^{7} \mathrm{spores} / \mathrm{ml}$. Three methods of sample preparation were investigated: (i) the spore suspension was directly added to the qPCR reactions; (ii) $100 \mu \mathrm{l}$ of the spore suspension was mechanically disrupted by shaking on a vortex machine with 0.1-mm glass beads (Biospec Products, Inc.), followed by freezing the samples for $3 \mathrm{~min}$ at $-20^{\circ} \mathrm{C}$, heating them

Table 3. Species-specific TaqMan primer and probe oligonucleotides targeting the internal transcribed spacer 1 (ITS-1) region for quantitative polymerase chain reaction assay

\begin{tabular}{|c|c|c|c|}
\hline Assay, designation & Type & Sequences $\left(5^{\prime}\right.$ to $\left.3^{\prime}\right)$ and labeling ${ }^{a}$ & Amplicon length (bp) \\
\hline \multicolumn{4}{|c|}{ Guignardia citricarpa (GCITS) } \\
\hline GCITSF1 & Forward primer & CCTGAAAGGTGATGGAAGGG & 84 \\
\hline GCITSR1 & Reverse primer & CGCCAAAGCAACATGGTAGATA & $\ldots$ \\
\hline GCITSP1 & TaqMan probe & Cy5-AGCCGCCCGACCTACCTTCA-Iowa black RQ & $\ldots$ \\
\hline \multicolumn{4}{|c|}{ G. mangiferae (GMITS) } \\
\hline GMITSF1 & Forward primer & CGGAAGGATCATTACTGAAATGTAATAAC & 111 \\
\hline GMITSR1 & Reverse primer & CGCCAAAGCAACATAGTGAG & $\ldots$ \\
\hline GMITSP1 & TaqMan probe & FAM-CGCTACAACGCCGAAATGACCTTCT-BHQ1 & $\ldots$ \\
\hline
\end{tabular}

a Probe labels are highlighted in bold and probes were phosphorylated at $3^{\prime}$ end. 
for $2 \mathrm{~min}$ at $65^{\circ} \mathrm{C}$, and finally placing them on ice for $5 \mathrm{~min}$; and (iii) $100 \mu \mathrm{l}$ of the spore suspension was mechanically disrupted as above and used for DNA extraction with the DNeasy Plant Mini Kit, per instructions. A final volume of $100 \mu \mathrm{l}$ of DNA eluate was obtained for each method.

Number of nuclei in spores. To determine nuclei numbers in spores of Guignardia spp., pycnidiospores and ascospores were collected as described above from pure cultures of G. citricarpa and $G$. mangiferae, respectively. The spores were stained with $4^{\prime}, 6-$ diamidino-2-phenylindole (DAPI; Invitrogen) following the manufacturer's instructions, with modifications. Briefly, spore suspensions were pipetted onto slides and exposed to approximately $70^{\circ} \mathrm{C}$ on a hot plate for $1 \mathrm{~min}$, allowing the slides to dry thoroughly. Subsequently, spores were treated with DAPI $(1 \mu \mathrm{g} / \mathrm{ml}$ dissolved in sterile distilled water) for 1 min and examined using a fluorescence microscope (LaborLux) at an excitation wavelength of $350 \mathrm{~nm}$ and emission wavelength of $425 \mathrm{~nm}$. Images were recorded with a Canon Powershot S3IS (Canon U.S.A. Inc.). ITS copy numbers of $G$. citricarpa and $G$. mangiferae were estimated by regressing the number of pycnidiospores in a qPCR reaction against the copy number determined by qPCR and dividing by the number of nuclei in a pycnidiospore.

Pseudothecia production in Valencia leaf litter. In all, 600 asymptomatic fresh Valencia leaves were collected from trees of a citrus grove naturally infested by G. citricarpa in early April 2011. The leaves were air dried under ambient conditions for 2 weeks before the beginning of the experiment. Fifty leaves per treatment were placed into screen bags $\left(1-\mathrm{mm}^{2}\right.$ mesh) with three bags per treatment, for a total of 1,000 leaves. The leaves were wetted for $10,30,60,120$, or 180 min four times a week, then dried, and kept at temperatures of $20,24,28$, and $32^{\circ} \mathrm{C}$ in a factorial design. The fan in the $24^{\circ} \mathrm{C}$ incubator malfunctioned 2 weeks into the experiment, drying the leaves excessively; therefore, all $24^{\circ} \mathrm{C}$ treatments were removed from the analysis. One 7-mm-diameter leaf disk was cut from 10 arbitrarily selected leaves from each bag using a cork borer on 13 June and 21 July 2011. The density of Guignardia spp. pseudothecia per leaf disk was counted on three arbitrarily selected leaf disks per bag. Another five leaf discs per treatment were arbitrarily selected and pooled together for total gDNA extraction with the PowerSoil Kit with tissue homogenization via bead beating. In total, $100 \mu \mathrm{l}$ DNA elutes were obtained for each of 120 samples. The populations of G. citricarpa and G. mangiferae were assayed in all 120 samples with the GCITS and GMITS primer sets, as described above. The samples were run in triplicate with a standard curve and NTC on each plate. The sample target copy number was calculated from the standard curve.

Data analysis. Amplification efficiency was calculated using the formula $E=100 \times\left[\left(10^{-1 / \text { slope }}\right)-1\right]$, as calculated by the Bio-Rad CFX96 Real-Time PCR detection system software. To test whether there was significant difference in the slope of standard curves among treatments, an $F$ test from a one-way analysis of variance (PROC GLM; SAS ver. 9.0) was used. Linear regression lines were fitted between pycnidiospore number and plasmid copy number using PROC REG (SAS ver. 9.0).

The pseudothecia counts were transformed by $\log _{10}(X+1)$ prior to analysis to normalize the data. The data were analyzed with a generalized linear mixed model (PROC GLIMMIX; SAS ver. 9.3) where leaf disk, microscope field, and replicate were considered random variables and the log normal distribution was used. The proportion of $G$. citricarpa to $G$. mangiferae nuclei data were transformed by the fourth root to normalize the data before analysis. The analysis was performed with PROC GLIMMIX, where replicate and the replicate-date interaction were considered the random variables and the log normal distribution was used.

\section{Results}

Primer and probe design. The primer/probe sets GCITS for $G$. citricarpa and GMITS for G. mangiferae (Table 3) were designed based on the sequence alignment of the complete ITS regions of $G$. citricarpa, G. mangiferae, and P. citriasiana (Table 2) where there was the greatest differentiation among the three organisms. The expected amplicon sizes of 84 and 111 bp for G. citricarpa and $G$. mangiferae, respectively, from the corresponding PCR reactions were confirmed by sequencing (data not shown). Major secondary structures were not found in either set of primer and probes by the in silico analysis; primer-dimer formation was not observed for either set of primer pairs, as confirmed by the presence of a single specific product of the correct size in melt-curve analysis (data not shown). In addition, the specificity of the primers and probes were maximized and the potential for cross-reactivity and primer-probe interactions was minimized by calculating the estimated $\Delta \mathrm{G}$.

Specificity and optimization of qPCR protocols. Optimal efficiency was achieved by running both GCITS and GMITS assays with $400 \mathrm{nM}$ primer and $200 \mathrm{nM}$ probe concentrations. The optimal annealing temperature and $\mathrm{MgCl}_{2}$ concentration were $59^{\circ} \mathrm{C}$ and $1.5 \mathrm{nM}$, respectively.

BLAST analysis showed that primer/probe sets GCITS and GMITS shared $100 \%$ sequence identity with $G$. citricarpa and $G$. mangiferae isolates, respectively, but less than $85 \%$ identity with sequences of other species deposited in GenBank, including each other. The exception was $P$. citriasiana, where there were only three mismatches in the primers and probe of G. citricarpa. The primer/probe sets GCITS and GMITS were highly specific to $G$. citricarpa and G. mangiferae, respectively, because neither primer set amplified PCR products from the DNA of each other, nontarget species of fungi, oomycetes nor bacteria (Table 1). No amplification was observed in the NTCs. Melt-curve analysis confirmed that GCITS and GMITS qPCR assays produced only one specific amplicon from their target gDNA samples but nothing from the negative controls and gDNA samples of other targets.

Standard curves for quantification. All standard curves for gDNA and pDNA had correlation coefficients greater than 0.99 (Figs. 1 and 2). Cycle threshold values were linear over the range of target DNA tested. Amplification efficiencies of the GCITS assays were 99.3 and $98.4 \%$ for gDNA and pDNA, respectively (Fig. 1A). The GMITS assays had amplification efficiencies of 98.4 and $91.6 \%$ for gDNA and pDNA, respectively (Fig. 1B). Statistical comparisons of the standard regression line slopes did not show a significant difference between gDNA and pDNA for either fungus $(P<0.328, G$. citricarpa and $P<0.166, G$. mangiferae). Both the GCITS and GMITS assays can reliably detect as little as $10 \mathrm{fg}$ of gDNA and 10 copies of pDNA (Fig. 1). The linear equation for each type of amplification curve is given in Figure 1.

At concentrations as low as $10 \mathrm{fg}$ of gDNA, G. mangiferae gDNA template $(10 \mathrm{ng})$ did not interfere with the amplification or quantification of G. citricarpa (Fig. 2A) and vice versa (Fig. 2B). No significant differences among the slopes of the standard amplification curves in the presence or absence of the gDNA of the other fungus were found $(P<0.802, G$. citricarpa and $P<0.907$, G. mangiferae).

Inhibitive effect of host DNA extracts on qPCR assay. Extracts of partially decomposed leaves were spiked with $10^{5}$ copies of either pGC1 or pGM1. The number of target DNA molecules detected for each fungus in DNA extracts from the PowerSoil DNA isolation kit and the 1/100 dilution of the DNeasy Plant Mini kit extract matched the expected numbers (Fig. 3). No amplification was detected with the undiluted DNA template extracted with DNeasy Plant Mini kit, indicating complete inhibition causing false-negative results (Fig. 3). After 1/10 dilution of the DNeasy Plant Mini kit elutes, partial inhibition of G. citricarpa amplification occurred (Fig. 3A) but no inhibition of G. mangiferae amplification was detected.

No significant differences $(P<0.798, G$. citricarpa and $P<$ 0.594, G. mangiferae) were found among slopes of pDNA standard curves (pGC1 and pGM1) in the DNA extract backgrounds tested. These included sterile distilled water, fresh leaves extracted with the DNeasy Plant Mini kit, and partially decomposed leaves extracted with the PowerSoil DNA isolation kit with bead beating (Fig. 4). These results confirmed the results of the spiking experi- 
ments and indicated that there was little or no inhibitory effect of fresh citrus leaf DNA or partially decomposed leaf DNA extracted with the PowerSoil DNA isolation kit on the DNA amplification and quantification of both GCITS and GMITS assays.

Standard curves for quantifying pycnidiospores and nuclei in spores. When pycnidiospore suspensions were disrupted using the beads and freeze-thaw treatment, the DNA from a single spore was detected in both GCITS and GMITS assays. The DNA from 100 pycnidiospores was consistently detected with the other two pycnidiospore preparation methods (Fig. 5). The linear regression equations fitted to the experimental results are given in Figure 5. The equations allow for the calculation of the number of ITS copies per pycnidiospore. A G. citricarpa pycnidiospore was estimated to contain 78 copies of the ITS, with a $95 \%$ confidence interval of 59 to 102 copies. A G. mangiferae pycnidiospore was estimated to contain 112 copies of the ITS, with a $95 \%$ confidence interval of 92 to 136 copies. The single-celled pycnidiospores of $G$. citricarpa and $G$. mangiferae were observed to have two nuclei each through DAPI staining (Fig. 6). The G. mangiferae ascospores, also single celled, had four nuclei. It was not possible to obtain $G$. citricarpa ascospores to count nuclei because they are not formed in culture. They are morphologically identical to G. mangiferae when trapped from the air and cannot be distinguished except through PCR. Because they are so similar to G. mangiferae and the conidia have the same number of nuclei, it is expected that $G$. citricarpa ascospores have four nuclei. From the number of nuclei per pycnidiospore and the number of ITS per spore, it was estimated for further calculations that there were 50 ITS copies per nucleus for each fungus.

Pseudothecia production in Valencia leaf litter. The Guignardia spp. pseudothecia tended to be more evenly scattered across the partially decomposed leaf surfaces rather than the tightly

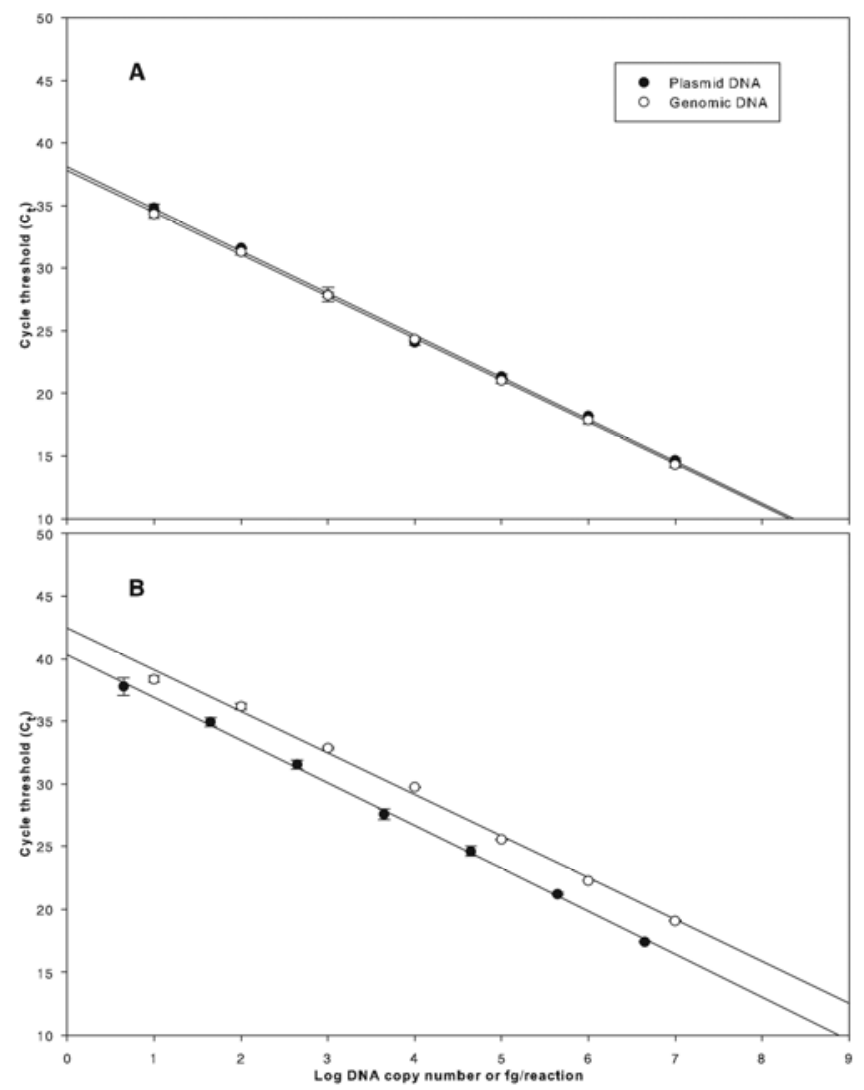

Fig. 1. Standard curves of plasmid and genomic DNA for A, Guignardia citricarpa: plasmid: cycle threshold $\left(C_{t}\right)=38.09-3.36 \times \log$ (copy number/reaction); correlation coefficient $\left(R^{2}\right)=0.995$; genomic DNA: $C_{\mathrm{t}}=37.80-3.34 \times \log$ (fg/reaction); $R^{2}=0.997$; and $\mathrm{B}, \mathrm{G}$. mangiferae: plasmid: $C_{\mathrm{t}}=40.92-3.54 \times \log$ (copy number/ reaction); $R^{2}=0.996$; genomic DNA: $C_{t}=42.64-3.36 \times \log$ (fg/reaction); $R^{2}=$ 0.995. Each point represents the mean of three replicates. Error bar represents the standard error of the mean. clustered pseudothecia with $M$. citri (30), although some leaves had sections where pseudothecia were present and others where there were no pseudothecia visible. No morphological characteristics were observed that distinguished the two Guignardia spp. visually when embedded in the leaf tissue. Temperature and the quadratic term of temperature had significant effects $(P<0.0001)$ on the number of pseudothecia per microscope field. The wetting period also had a significant effect $(P<0.003)$ on the number of pseudothecia per microscope field. Sampling date was tested but did not have a significant effect and was dropped from the model. The peak number of pseudothecia produced at $28^{\circ} \mathrm{C}$ was observed at $60 \mathrm{~min}$ of wetting (Fig. 7A). The trend was less clear at $32^{\circ} \mathrm{C}$ but there was a peak at 60 min of wetting as well.

When the proportion of $G$. citricarpa to $G$. mangiferae nuclei was compared (Fig. 7B), temperature had a minor effect $(P=$ $0.08)$, although the wetting period had a greater influence $(P<$ 0.014). The quadratic effect of temperature and the interaction between temperature and wetting period were not significant and were dropped from the analysis. There was a weak effect of sampling date on the proportion of $G$. citricarpa to $G$. mangiferae nuclei $(P=0.05)$ and the interaction of date and temperature was significant $(P<0.032)$. The sampling dates were combined for presentation. Overall, there were between $10^{1}$ and $10^{3}$ times more $G$. mangiferae nuclei than G. citricarpa at all temperatures and wetting periods.

\section{Discussion}

New sets of qPCR primers and probes for G. citricarpa and $G$. mangiferae were developed for detection of these fungi in environmental samples. From the ITS, actin, and Tef- $1 \alpha$ sequences available in the GenBank databases for G. citricarpa and G. mangiferae, the sequences with least homology and deleterious interactions

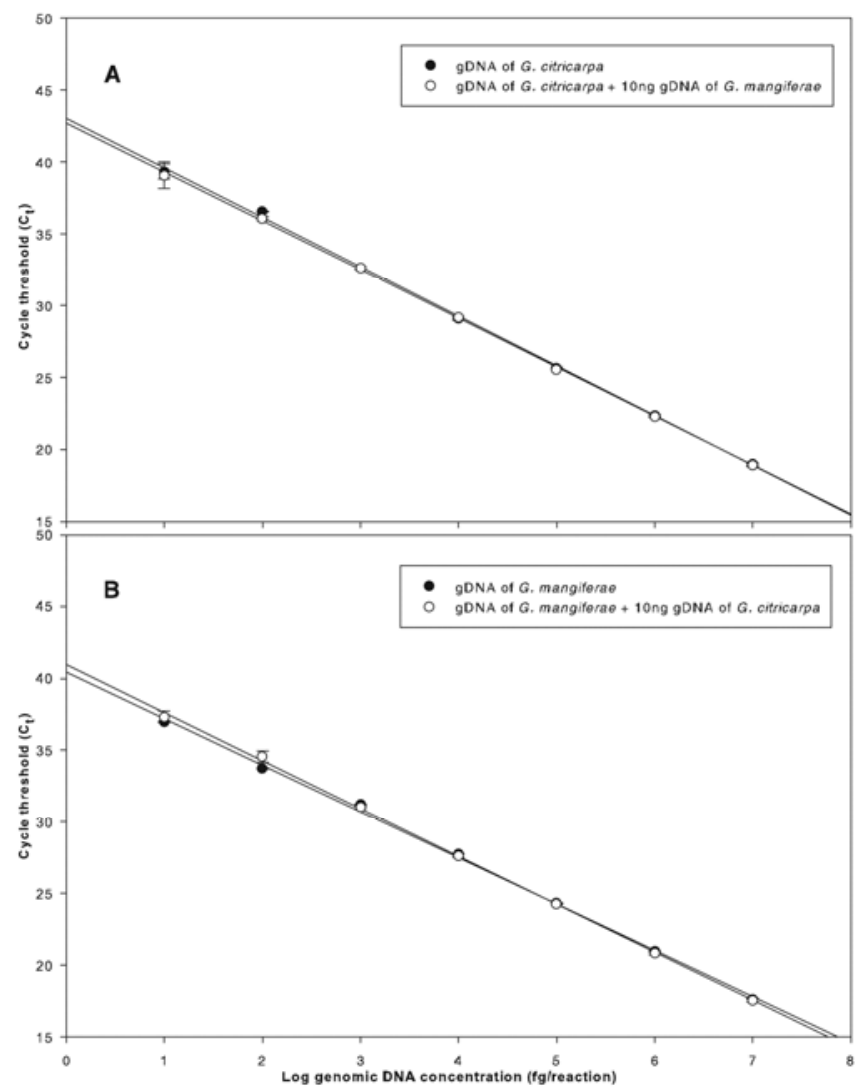

Fig. 2. Standard curves of genomic (g)DNA of A, Guignardia citricarpa in backgrounds of sterile water (cycle threshold $\left[C_{t}\right]=42.93-3.43 \times \log [\mathrm{fg} / \mu \mathrm{l} \mathrm{gDNA}]$; correlation coefficient $\left.\left[R^{2}\right]=0.998\right)$ and gDNA of $G$. mangiferae at $10 \mathrm{ng} / \mu \mathrm{l}\left(\mathrm{C}_{\mathrm{t}}=\right.$ $\left.42.73-3.41 \times \log [\mathrm{fg} / \mathrm{\mu l} \mathrm{gDNA}] ; R^{2}=0.997\right) ;$ and $\mathrm{B}, \mathrm{G}$. mangiferae in backgrounds of sterile water $\left(\mathrm{C}_{\mathrm{t}}=40.5-3.24 \times \log [\mathrm{fg} / \mu \mathrm{gDNA}], R^{2}=0.998\right)$ and gDNA of $G$. citricarpa at $10 \mathrm{ng} / \mu \mathrm{l}\left(\mathrm{C}_{\mathrm{t}}=41.06-3.35 \times \log [\mathrm{fg} / \mu \mathrm{gDNA}], R^{2}=0.998\right)$. 
between primer/probe sets were from the ITS. Many of the 20-plus primer/probe designs were discarded because of the in silico prediction of primer dimers, poor melt-curve results, or PCR inhibition (data not shown). Another advantage of targeting the ITS was its high copy number in the genome, which can make detection more sensitive at low fungal densities (8). Although more gene copies increase sensitivity, if copy number varies by isolate, this can introduce more variation into a data set. In initial testing, GCITS and GMITS appeared to work well in a duplex reaction; however, more in-depth analysis showed that there was a template DNA concentration-dependent inhibition of the qPCR reaction for the lower concentration template when there was a greater than $10^{3}$ copy number/reaction difference. Furthermore, it did not matter which template was in the greater concentration; inhibition was slightly higher with a greater concentration of G. mangiferae DNA. To complicate matters, the inhibition did not always occur and it was not possible to predict when it would happen. From this experience, it is recommended that any primers and probes that are to be used in duplex qPCR be tested for concentration-dependent inhibition. For this reason, the primers and probes were used in separate rather than duplex reactions. As single primer/probe set reactions, there was no evidence of any inhibition.
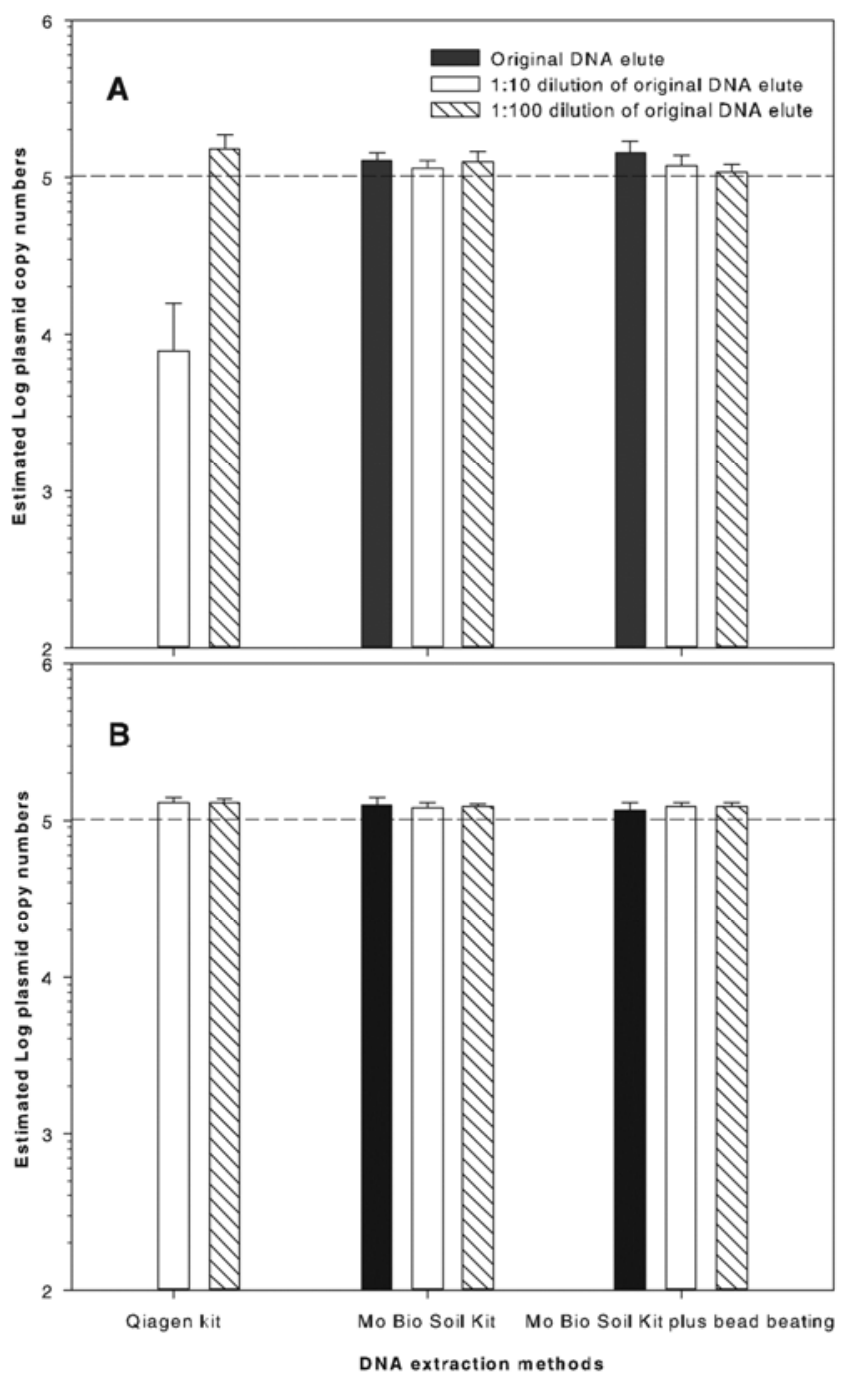

Fig. 3. Inhibition tests of quantitative polymerase chain reaction assays by spiking DNA samples with $10^{5}$ plasmid DNA copies of pGC1 and pGM1 for A, Guignardia citricarpa and B, G. mangiferae, respectively. The dotted line represents the expected log plasmid copy number. DNA was extracted from partially decomposed citrus leaves with the Qiagen DNeasy Plant Kit, the Mo Bio PowerSoil DNA kit, and the Mo Bio PowerSoil DNA isolation kit with tissue homogenization via bead beating. The log plasmid copy number is the mean of three wells and error bars are standard error of the mean.
The new primers and probes do not amplify products from the other fungus of interest or from the other citrus-associated fungi, oomycetes, and bacteria tested in this study. Attempts to acquire DNA from $P$. citriasiana to test our primers and probes were unsuccessful. From an alignment, there was limited homology between the primers and probes for $G$. mangiferae and the ITS of $P$. citriasiana but there were only three mismatches between $P$. citriasiana and $G$. citricarpa. There may be some cross reaction between these two organisms because there are reports of other $G$. citricarpa-specific primers amplifying products from $P$. citriasiana (41). However, to date, $P$. citriasiana has not been reported to occur outside of Southeast Asia; therefore, it is unlikely to be a problem for field studies in Florida $(45,46)$. Two newer species of citrus-associated Phyllosticta have been described since this study was initiated $(17,45)$. The primers and probes for both target species were compared with $P$. citribraziliensis and $P$. citrichinaensis and low sequence identity was found with the forward primer and probe $(<70 \%)$ of GCITS, although they were nearly identical for the reverse primer. For GMITS, the forward primer had two mismatched base pairs but there was $80 \%$ identity with the reverse primer and $41 \%$ identity with the probe. Therefore, it is suspected

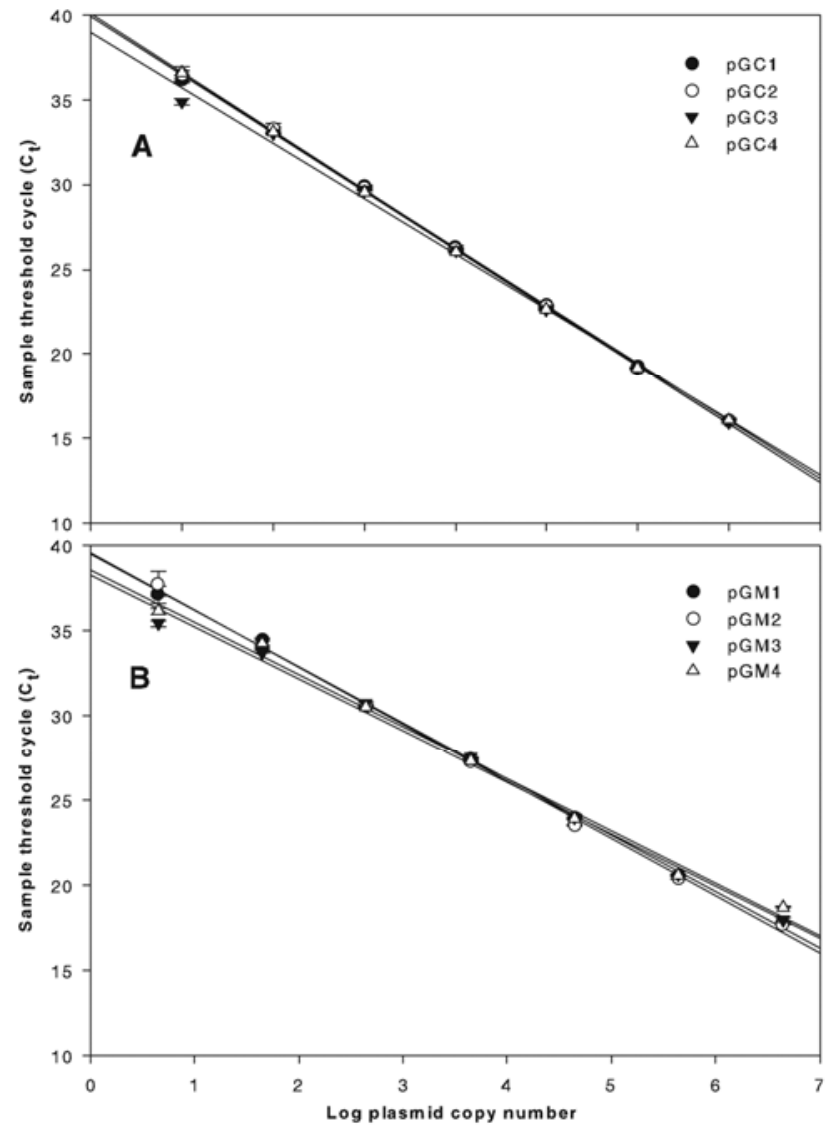

Fig. 4. Effect of different plant extracts on the standard curves of $\mathbf{A}, 10$-fold serial dilution of plasmid pGC1 $\left(2.50 \times 10^{6} \mathrm{copies} / \mu \mathrm{l}\right)$ diluted in nuclease-free water (pGC1: cycle threshold $\left[\mathrm{C}_{t}\right]=39.90-3.41 \times \log$ [copy number/reaction]; correlation coefficient $\left.\left[R^{2}\right]=0.999\right)$, in total DNA extract from healthy citrus leaves at 40 $\mathrm{ng} /$ reaction (pGC2: $\mathrm{C}_{\mathrm{t}}=40.06-3.45 \times \log$ [copy number/reaction]; $R^{2}=0.998$ ), partially decomposed leaves (pGC3: $C_{t}=38.99-3.26 \times \log$ [copy number/ reaction]; $R^{2}=0.995$ ), and a 10 -fold dilution of the decomposed leaf extract (pGC4: $C_{t}=39.94-3.44 \times \log$ [copy number/reaction]; $R^{2}=0.999$ ); and $\mathrm{B}, 10$-fold serial dilution of plasmid pGM1 DNA $\left(1.11 \times 10^{6}\right.$ copies $\left./ \mu l\right)$ diluted in nuclease-free water (pGM1: $C_{t}=39.49-3.31 \times \log$ [copy number/reaction]; $R^{2}=0.997$ ), in total DNA extract from healthy citrus leaves at $40 \mathrm{ng} /$ reaction $\left(\mathrm{pGM} 2: \mathrm{C}_{\mathrm{t}}=39.62-3.37 \times \log \right.$ [copy number/reaction]; $\left.R^{2}=0.995\right)$, partially decomposed leaves (pGM3: $C_{t}=$ $38.25-3.05 \times \log$ [copy number/reaction]; $R^{2}=0.993$ ), and a 10 -fold dilution of the decomposed leaf extract (pGM4: $\mathrm{C}_{\mathrm{t}}=38.60-3.08 \times \log$ [copy number/reaction]; $R^{2}$ $=0.993)$. Healthy citrus leaves were extracted with the Qiagen DNeasy Plant Kit and the decomposed leaves were extracted with the Mo Bio PowerSoil DNA kit with tissue homogenization via bead beating. 
that amplification is unlikely with GCITS or GMITS. It would be advisable to confirm the lack of cross reaction before using these primers in locations with these fungi.

The G. citricarpa life cycle includes a saprophytic phase in the leaf litter. Little is known about the leaf litter cycle of this organism but a better understanding is critical for improved black spot control because the leaf litter is where the primary inoculum, ascospores, are formed $(21,22)$. The citrus endophyte $G$. mangiferae also completes its life cycle in the leaf litter but even less is known about this fungus, although it has led to confusion in the literature $(4,24)$. To be able to study the relative abundance and seasonal change of G. citricarpa and G. mangiferae density in leaf litter, it is necessary to be able to quantify the biomass of the two fungi. Reliably extracting high-quality DNA from partially decomposed citrus leaf litter was problematic. The Qiagen plant kit worked well for extraction from mycelia and live citrus leaf tissue but did not work well for the leaf litter. The extracts were discolored and required at least a 1:10 dilution to detect $10^{5}$ plasmid copies of target sequence and a 1:100 dilution was needed to reliably detect $G$. citricarpa. Even with dilution, evidence of inhibitors was observed because the qPCR amplification curves were shallower than the

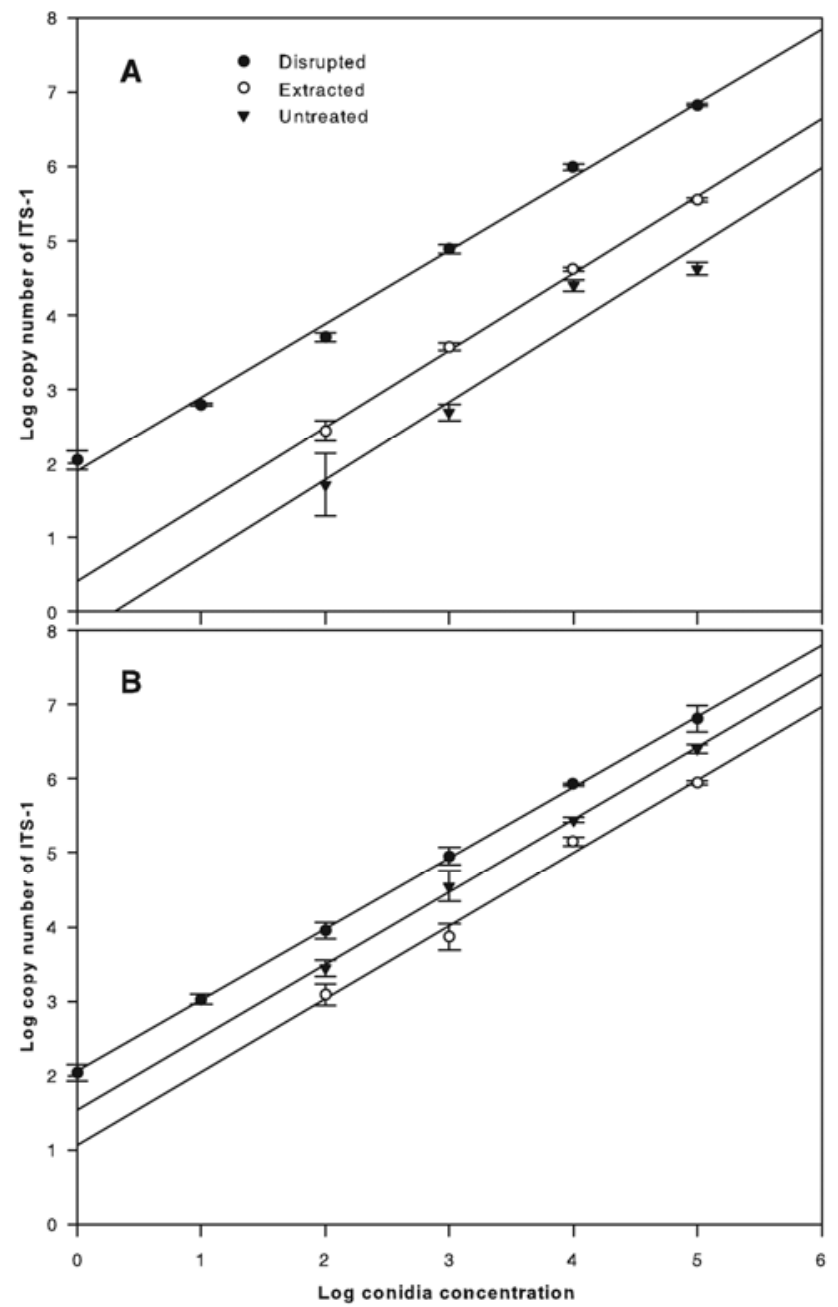

Fig. 5. Relationship between log conidia number and log copy number of internal transcribed spacer (ITS)-1 for A, Guignardia citricarpa and B, G. mangiferae. Three pycnidiospore DNA extraction methods were tested: conidia disruption ( $G$. citricarpa: $\log$ copy number $=1.89+0.99 \log$ conidia, correlation coefficient $\left[R^{2}\right]=$ 0.995; G. mangiferae: log copy number $=2.05+0.959 \log$ conidia, $R^{2}=0.997$ ), conidia disruption and DNA extraction (G. citricarpa: log copy number $=0.40+1.03$ $\log$ conidia, $R^{2}=0.995 ; G$. mangiferae: $\log$ copy number $=1.07+0.99 \log$ conidia, $R^{2}=0.982$ ), and undisrupted spores $(G$. citricarpa: log copy number $=0.31+1.05$ $\log$ conidia, $R^{2}=0.913 ; G$. mangiferae: $\log$ copy number $=1.53+0.98 \log$ conidia, $\left.R^{2}=0.991\right)$. Each data point is the mean of three replicates and the error bars represent the standard error. positive control (data not shown). The need for dilution to get consistent amplification creates the additional problem of reduced detection sensitivity of 10 or 100 times. This is undesirable when dealing with potentially low concentrations of target organisms in tissues. With the modified Mo Bio Soil Kit protocol, there was little evidence of inhibition at any dilution in most samples. Occasionally, a sample would have poor amplification. For these rare samples, dilution is advised. It may be necessary to develop an internal control to quantify inhibition in leaf litter samples for future experiments. A caveat is that, if not carefully designed, an internal control can lead to amplification competition in a duplex situation (8), not unlike what was observed when GCITS and GMITS were used in a single reaction. Not only was it possible to extract highquality DNA from leaf litter but there also were no differences in amplification among the plant extract types that are expected to be used with this assay so that comparisons can be made.

One of the applications of the qPCR protocol was to quantify the number of spores in environmental samples. Conidia were chosen to demonstrate that this was possible because both fungi produce conidia on media whereas $G$. citricarpa does not produce pseudothecia or ascospores on media $(4,17)$. Cell disruption was the most efficient method for detection of conidia for both fungi, with the ability to detect 1 conidium/reaction. Extraction of conidia with cell disruption had the same sensitivity as untreated conidia and, therefore, is not recommended. Once the number of nuclei per conidium was determined, it was possible to calculate the

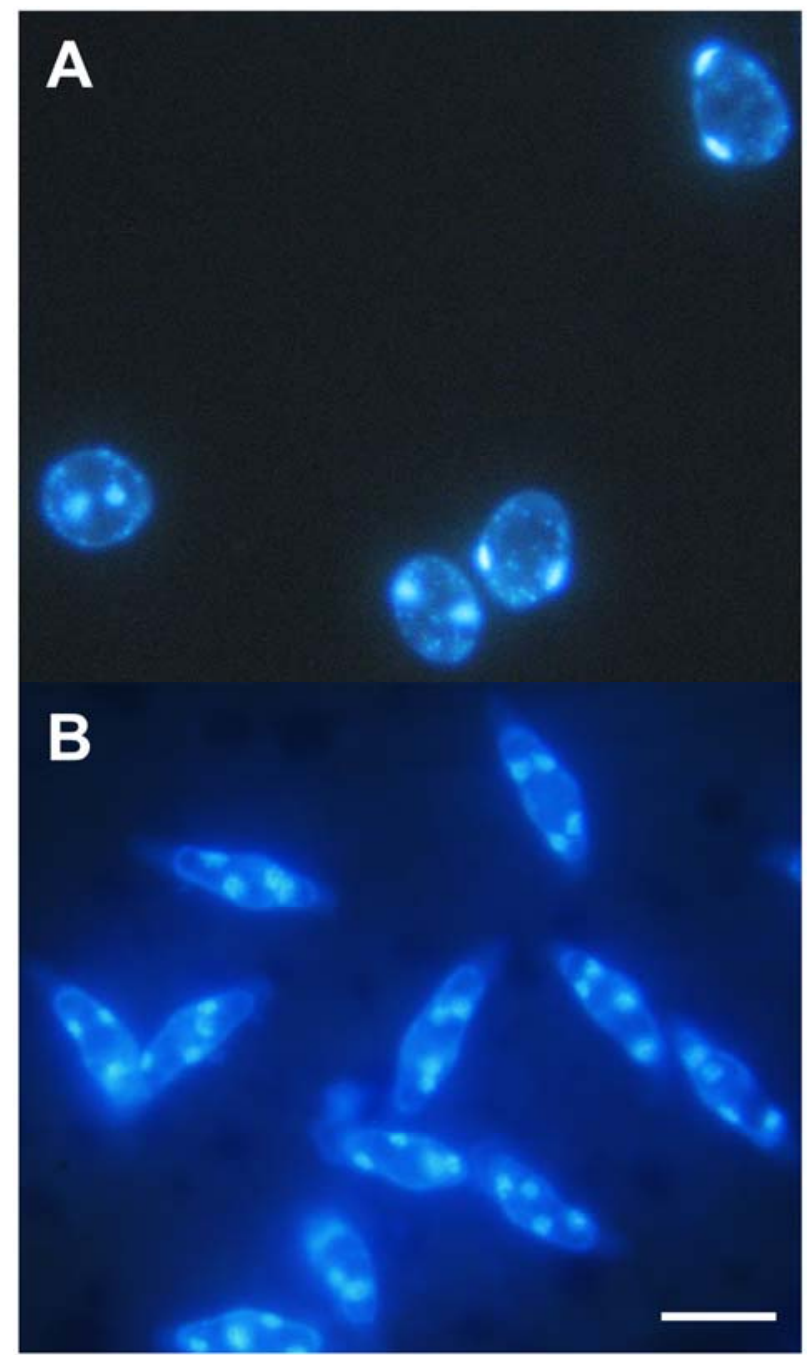

Fig. 6. Nucleus staining: A, binucleated pycnidiospores of Guignardia citricarpa and B, multinucleated ascospores of $G$. mangiferae. Pycnidiospores and ascospores, collected from pure cultures of $G$. citricarpa and $G$. mangiferae, respectively, were stained with 4',6-diamidino-2-phenylindole. The scale bar is $10 \mu \mathrm{m}$. 
approximate number of ITS copies per nuclei from the dilution series of conidia. The ITS estimates of 30 to 51 copies per nuclei for G. citricarpa and 46 to 68 for G. mangiferae can then be used to calculate the number of nuclei in samples as an approximation of biomass where it is not possible to count individuals, such as in leaves or leaf litter. In leaves, G. citricarpa forms a small knot of fungal tissue below an infection peg that, in most cases, appears to remain dormant until the abscission of the leaves; however, what occurs after $96 \mathrm{~h}$ post inoculation is unclear (27). In the rare case of lesion formation, some hyphae were observed in the center of older lesions and around the edges of those that were no longer expanding (27). Some pycnidia were formed in old lesions on intact leaves but, on the whole, until abscission there is minimal fungal biomass to detect, especially in live leaves where symptoms have not formed. It is unknown whether $G$. mangiferae follows a similar pattern of a long dormant period while a leaf is still living or if it grows as an endophyte before abscission. It was reported in studies from Brazil (2) and Argentina (12) that G. citricarpa was a very frequent leaf endophyte in asymptomatic citrus leaves. Unfortunately, the fungi were identified by morphology and no differentiation was made between $G$. citricarpa or G. mangiferae in either study by morphology or other means. It is very likely that the isolated citrus endophytes were Guignardia or Phyllosticta spp. $(4,17,45)$ but it is difficult to conclude that $G$. citricarpa was as common as described.

Our leaf litter experiment results suggest that $G$. mangiferae colonizes the leaves as an endophyte. The number of G. mangiferae nuclei, or biomass, was frequently detected to be 100 to 10,000 times higher than G. citricarpa in the naturally infected leaves. It has been known that $G$. mangiferae was associated with

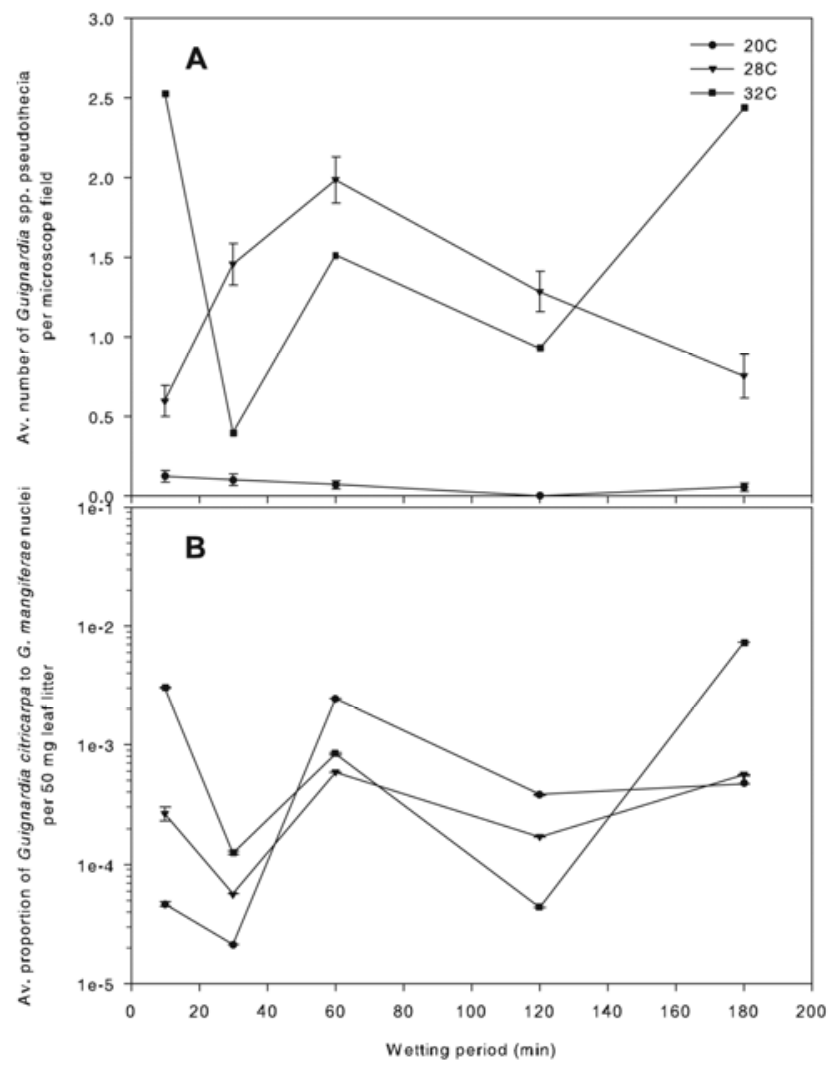

Fig. 7. A, Number per microscope field of Guignardia spp. pseudothecia from naturally inoculated partially decomposing 'Valencia' sweet orange leaves that were kept at 20,28 , or $32^{\circ} \mathrm{C}$ with wetting periods of $10,30,60,120$, or 180 min four times per week. B, Proportion of G. citricarpa to G. mangiferae nuclei as determined by quantitative polymerase chain reaction assays for each temperaturewetting period treatment. Count data were transformed by $\log _{10}(X+1)$ and proportion data were transformed with the fourth root for analysis. Data were back transformed for presentation. Error bars are standard error of the transformed mean and back transformed for presentation. citrus in Florida since at least the early 2000s (L. W. Timmer, personal communication) but the extent has been unknown. Because G. citricarpa is an invasive disease in Florida and G. mangiferae has likely been present for many years, it is not entirely unexpected that there would be a greater biomass of $G$. mangiferae present. The interaction between the relative biomass of the two species in areas where black spot has been present for many years is not known. However, G. mangiferae has long been associated with citrus and has confused the literature with reports of nonpathogenic and pathogenic G. citricarpa, including from Australia, Brazil, New Zealand, South Africa, and Taiwan $(4,6,13,23,24)$; therefore, it is probable that $G$. mangiferae has high relative biomass compared with $G$. citricarpa in these locations as well but not to the extent of Florida. It is also possible that G. mangiferae can colonize living leaf tissue extensively but that G. citricarpa remains latent until leaf abscission. The qPCR assay presented here can help answer these questions and untangle the interaction between these two fungal species found in similar ecological niches.

Temperature and wetting period affected how many pseudothecia were visible on the leaf surface, with the greatest number being formed at $28^{\circ} \mathrm{C}$ with $60 \mathrm{~min}$ of wetting four times per week. This optimal temperature was the same for pseudothecia production of $M$. citri but the optimal wetting period was $30 \mathrm{~min}$ (31). The low number of pseudothecia per microscope field at $20^{\circ} \mathrm{C}$ is potentially due, in part, to the relative humidity in the incubator being very low (approximately 20\%) because of the refrigeration mechanism. In preliminary data, if the humidity is increased to at least $40 \%$, more pseudothecia were formed at $20^{\circ} \mathrm{C}$ (data not shown). A similar effect was observed with $M$. citri, where the pseudothecial density of $M$. citri did increase slightly when the leaves were kept at $100 \%$ relative humidity (31). Further temperature and wetting period experiments, including the effect of relative humidity, will be needed to confirm the data presented here. Although the qPCR data cannot directly determine the proportion of $G$. citricarpa to $G$. mangiferae pseudothecia that were formed in each treatment, it can indicate the effects of temperature and wetting period on the relative biomass of the two fungi. In this experiment, the proportion of $G$. citricarpa nuclei to $G$. mangiferae nuclei was affected to a greater extent by wetting period than temperature and there was no quadratic effect of temperature. This is a detail that would have been missed if only visual identification had been used; therefore, the qPCR assay extracted additional richness from the experiment. To further emphasize that the qPCR data can enhance the visual identification data, Supplementary Figure S2 shows the leaf litter experiment with the $24^{\circ} \mathrm{C}$ data included. We removed the data from the experiment because the leaf litter used for this treatment was collected after the other treatments due to an incubator failure. From the visual data, the $24^{\circ} \mathrm{C}$ pseudothecia counts are at levels that could be expected from the other temperatures but the qPCR data show that the proportion of G. citricarpa to G. mangiferae nuclei is far lower than all other treatments. Whether this difference is due to temperature differences or because these leaves were collected separately is unknown.

The qPCR assays for G. citricarpa and G. mangiferae were able to distinguish between these two fungi (pathogen and endophyte, respectively) in environmental samples, including leaf litter. This will be an invaluable tool to better understand the leaf cycle of $G$. citricarpa and how G. mangiferae affects it. It will also allow for the evaluation of the relative effect of leaf litter decomposition methods on the two fungi, an area of active research. In commercial groves, ascospores produced from leaf litter are the major source of infection. Despite the importance of leaf litter in the black spot disease cycle and $G$. citricarpa life cycle, how the pathogen develops in the leaf litter has not been well examined. Formerly, tools were limited for differentiating between the two fungi but qPCR will allow us to differentiate and quantify both fungi in biological samples. To better manage black spot, it is important to understand the environmental factors that contribute to the formation of pseudothecia in the leaf litter. It is not known whether $G$. citricarpa and G. mangiferae have the same environmental require- 
ments for sporulation, infection, and host colonization or if they compete for the same ecological niche. If competition occurs, what are the consequences for disease management? The qPCR assays combined with more traditional means of detection will be a very powerful tool for answering the questions above which, in turn, will help improve citrus black spot management.

\section{Acknowledgments}

This research was supported by funding from the United States Department of Agriculture (USDA) Animal Plant Health Inspection Service and the USDA Tropical and Subtropical Agricultural Research program. We thank J. A. Rollins and L. W. Duncan for their critical reviews.

\section{Literature Cited}

1. Agostini, J. P., Peres, N. A., Mackenzie, S. J., Adaskaveg, J. E., and Timmer, L. W. 2006. Effect of fungicides and storage conditions on postharvest development of citrus black spot and survival of Guignardia citricarpa in fruit tissues. Plant Dis. 90:1419-1424.

2. Araujo, W. L., Maccheroni, W., Jr., Aguilar-Vildoso, C. I., Barroso, P. A. V., Saridakis, H. O., and Azevedo, J. L. 2001. Variability and interactions between endophytic bacteria and fungi isolated from leaf tissues of citrus rootstocks. Can. J. Microbiol. 47:229-236.

3. Atallah, Z. K., Bae, J., Jansky, S. H., Rouse, D. I., and Stevenson, W. R. 2007. Multiplex real-time quantitative PCR to detect and quantify Verticillium dahliae colonization in potato lines that differ in response to Verticillium wilt. Phytopathology 97:865-872.

4. Baayen, R. P., Bonants, P. J. M., Verkley, G., Carroll, G. C., van der Aa, H. A., de Weerdt, M., van Brouwershaven, I. R., Schutte, G. C., Maccheroni, W., de Blanco, C. G., and Azevedo, J. L. 2002. Nonpathogenic isolates of the citrus black spot fungus, Guignardia citricarpa, identified as a cosmopolitan endophyte of woody plants, G. mangiferae (Phyllosticta capitalensis). Phytopathology 92:464-477.

5. Baayen, R. P., Meffert, J. P., Bonants, P. J. M., Carroll, G. C., and Kox, L. F. F. 2009. Guignardia citricarpa. EPPO Bull. 39:318-357.

6. Baldassari, R. B., Wickert, E., and de Goes, A. 2008. Pathogenicity, colony morphology and diversity of isolates of Guignardia citricarpa and G. mangiferae isolated from Citrus spp. Eur. J. Plant Pathol. 120:103-110.

7. Bellotte, J. A. M., Kupper, K. C., Rinaldo, D., Souza, A. d., Pereira, F. D., and Goes, A. d. 2009. Acceleration of the decomposition of Sicilian lemon leaves as an auxiliary measure in the control of citrus black spot. Trop. Plant Pathol. 34:71-76.

8. Bilodeau, G. J., Koike, S. T., Uribe, P., and Martin, F. N. 2012. Development of an assay for rapid detection and quantification of Verticillium dahliae in soil. Phytopathology 102:331-343.

9. Bonants, P. J. M., Carroll, G. C., de Weerdt, M., van Brouwershaven, I. R., and Baayen, R. P. 2003. Development and validation of a fast PCR-based detection method for pathogenic isolates of the citrus black spot fungus, Guignardia citricarpa. Eur. J. Plant Pathol.109:503-513.

10. Crouch, J. A., and Szabo, L. J. 2011. Real-time PCR detection and discrimination of the southern and common corn rust pathogens Puccinia polysora and Puccinia sorghi. Plant Dis. 95:624-632.

11. Dewdney, M. M., Schubert, T. S., Estes, M. R., and Peres, N. A. 2013. Citrus black spot. Pages 81-85 in: 2013 Florida Citrus Pest Management Guide. M. E. Rogers and M. M. Dewdney, eds. Institute of Food and Agricultural Services, Gainesville, FL.

12. Durán, E. L., Ploper, L. D., Ramallo, J. C., Grandi, R. A. P., Giancoli, A. C. H., and Azevedo, J. L. 2005. The foliar fungal endophytes of Citrus limon in Argentina. Can. J. Bot. 83:350-355.

13. Everett, K. R., and Rees-George, J. 2006. Reclassification of an isolate of Guignardia citricarpa from New Zealand as Guignardia mangiferae by sequence analysis. Plant Pathol. 55:194-199.

14. Everett, K. R., and Rees-George, J. 2006. Species-specific PCR primers for Guignardia citricarpa and Guignardia mangiferae. N.Z. Plant Prot. 59:141-145.

15. Fourie, P., Schutte, T., Serfontein, S., and Swart, F. 2013. Modeling the effect of temperature and wetness on Guignardia pseudothecium maturation and ascospore release in citrus orchards. Phytopathology 103:281-292.

16. Gadoury, D. M., and Machardy, W. E. 1982. Effects of temperature on the development of pseudothecia of Venturia inaequalis. Plant Dis. 66:464-468.

17. Glienke, C., Pereira, O. L., Stringari, D., Fabris, J., Kava-Cordeiro, V., Galli-Terasawa, L., Cunnington, J., Shivas, R. G., Groenewald, J. Z., and Crous, P. W. 2011. Endophytic and pathogenic Phyllosticta species, with reference to those associated with Citrus Black Spot. Persoonia 26:47-56.

18. Glienke-Blanco, C., Aguilar-Vildoso, C. I., Vieira, M. L. C., Barroso, P. A. V., and Azevedo, J. L. 2002. Genetic variability in the endophytic fungus Guignardia citricarpa isolated from citrus plants. Gen. Mol. Biol. 25:251-255.

19. Huang, C. S., and Chang, S. L. 1972. Leaf infection with citrus black spot and perithecial development in relation to ascospore discharge of Guignardia citricarpa Kiely. J. Taiwan Agric. Res. 21:256-263.

20. Ioos, R., Fabre, B., Saurat, C., Fourrier, C., Frey, P., and Marçais, B. 2009. Development, comparison, and validation of real-time and conventional PCR tools for the detection of the fungal pathogens causing brown spot and red band needle blights of pine. Phytopathology 100:105-114.
21. Kiely, T. B. 1948. Preliminary studies of Guignardia citricarpa N.S.: the ascigerous state of Phoma citricarpa McAlp. and its relation to black spot of citrus. Proc. Linn. Soc. N. S. W. 73:249-292.

22. Kotzé, J. M. 1981. Epidemiology and control of citrus black spot in South Africa. Plant Dis. 65:945-950

23. Kotzé, J. M. 2000. Black spot. Pages 23-25 in: Compendium of Citrus Diseases, L. W. Timmer, S. M. Garnsey, and J. H. Graham, eds. American Phytopathological Society, St. Paul, MN.

24. McOnie, K. C. 1964. Latent occurrence in citrus and other hosts of Guignardia easily confused with $G$. citricarpa citrus black spot pathogen. Phytopathology 54:40-43.

25. McOnie, K. C. 1964. Orchard development and discharge of ascospores of Guignardia citricarpa and onset of infection in relation to control of citrus black spot. Phytopathology 54:1448-1453.

26. McOnie, K. C. 1964. Source of inoculum of Guignardia citricarpa citrus black spot pathogen. Phytopathology 54:64-67.

27. McOnie, K. C. 1967. Germination and infection of citrus by ascospores of Guignardia citricarpa in relation to control of black spot. Phytopathology 57:743-746.

28. Meyer, L., Sanders, G. M., Jacobs, R., and Korsten, L. 2006. A one-day sensitive method to detect and distinguish between the citrus black spot pathogen Guignardia citricarpa and the endophyte Guignardia mangiferae. Plant Dis. 90:97-101.

29. Meyer, L., Slippers, B., Korsten, L., Kotze, J. M., and Wingfield, M. J. 2001. Two distinct Guignardia species associated with citrus in South Africa. South Afr. J. Sci. 97:191-194.

30. Mondal, S. N., Howd, D. S., Brlansky, R. H., and Timmer, L. W. 2004 Mating and pseudothecial development in Mycosphaerella citri, the cause of citrus greasy spot. Phytopathology 94:978-982.

31. Mondal, S. N., and Timmer, L. W. 2002. Environmental factors affecting pseudothecial development and ascospore production of Mycosphaerella citri, the cause of citrus greasy spot. Phytopathology 92:1267-1275.

32. Paul, I., van Jaarsveld, A. S., Korsten, L., and Hattingh, V. 2005. The potential global geographical distribution of citrus black spot caused by Gui gnardia citricarpa (Kiely): likelihood of disease establishment in the European Union. Crop Prot. 24:297-308

33. Peres, N. A., Harakava, R., Carroll, G. C., Adaskaveg, J. E., and Timmer, L. W. 2007. Comparison of molecular procedures for detection and identification of Guignardia citricarpa and G. mangiferae. Plant Dis. 91:525-531.

34. Reis, R. F., Timmer, L. W., and de Goes, A. 2006. Effect of temperature, leaf wetness, and rainfall on the production of Guignardia citricarpa ascospores and on black spot severity on sweet orange. Fitopatol. Bras. 31:29-34.

35. Samuelian, S. K., Greer, L. A., Savocchia, S., and Steel, C. C. 2010. Detection and monitoring of Greeneria uvicola and Colletotrichum acutatum development on grapevines by real-time PCR. Plant Dis. 95:298-303.

36. Schubert, T. S., Dewdney, M. M., Peres, N. A., Palm, M. E., Jeyaprakash, A., Sutton, B., Mondal, S. N., Wang, N. Y., Rascoe, J., and Picton, D. D. 2012. First report of Guignardia citricarpa associated with citrus black spot on sweet orange (Citrus sinensis) in North America. Plant Dis. 96:1225.

37. Schutte, G. C., Mansfield, R. I., Smith, H., and Beeton, K. V. 2003. Application of azoxystrobin for control of benomyl-resistant Guignardia citricarpa on 'Valencia' oranges in South Africa. Plant Dis. 87:784-788.

38. Spósito, M. B., Amorim, L., Bassanezi, R. B., Filho, A. B., and Hau, B. 2008. Spatial pattern of black spot incidence within citrus trees related to disease severity and pathogen dispersal. Plant Pathol. 57:103-108.

39. Spósito, M. B., Amorim, L., Bassanezi, R. B., Yamamoto, P. T., Felippe, M. R., and Czermainski, A. B. C. 2011. Relative importance of inoculum sources of Guignardia citricarpa on the citrus black spot epidemic in Brazil. Crop Prot. 30:1546-1552.

40. Spósito, M. B., Amorim, L., Ribeiro, P. J., Bassanezi, R. B., and Krainski, E. T. 2007. Spatial pattern of trees affected by black spot in citrus groves in Brazil. Plant Dis. 91:36-40.

41. Stammler, G., Schutte, G. C., Speakman, J., Miessner, S., and Crous, P. W. 2013. Phyllosticta species on citrus: risk estimation of resistance to Qo fungicides and identification of species with cytochrome $b$ gene sequences. Crop Prot. 48:6-12.

42. Tatineni, S., Sagaram, U. S., Gowda, S., Robertson, C. J., Dawson, W. O. Iwanami, T., and Wang, N. 2008. In planta distribution of 'Candidatus Liberibacter asiaticus' as revealed by polymerase chain reaction (PCR) and real-time PCR. Phytopathology 98:592-599.

43. Trapero-Casas, A., and Kaiser, W. J. 1992. Development of Didymella rabiei, the teleomorph of Ascochyta rabiei on chickpea straw. Phytopathology 82:1261-1266.

44. van Gent-Pelzer, M. P. E., van Brouwershaven, I. R., Kox, L. F. F., and Bonants, P. J. M. 2007. A TaqMan PCR method for routine diagnosis of the quarantine fungus Guignardia citricarpa on citrus fruit. J. Phytopathol. $155: 357-363$

45. Wang, X., Chen, G., Huang, F., Zhang, J., Hyde, K. D., and Li, H. 2012 Phyllosticta species associated with citrus diseases in China. Fungal Divers. 52:209-224.

46. Wulandari, N. F., To-Anun, C., Hyde, K. D., Duong, L. M., de Gruyter, J., Meffert, J. P., Groenewald, J. Z., and Crous, P. W. 2009. Phyllosticta citriasiana sp. nov., the cause of Citrus tan spot of Citrus maxima in Asia. Fungal Divers. 34:23-39. 